\title{
Morphological and agronomic characterization of (Capsicum annuum L.) germplasm in Pakistan
}

\author{
Nadra Khan ${ }^{1 *}$, Muhammad Jamil Ahmed ${ }^{1}$, Syed Zulfiqar Ali Shah ${ }^{1}$, \\ Tariq Shehzad ${ }^{2}$, Maqsood Ahmed ${ }^{3}$, Saiqa Bashir ${ }^{4}$ and Abdul Hamid ${ }^{1}$ \\ 1. Department of Horticulture, Faculty of Agriculture, University of Poonch Rawalakot, 12350, AJK-Pakistan \\ 2. Department of Plant Breeding and Molecular Genetics, University of Georgia-USA \\ 3. Department of Biotechnology, Mirpur university of science and technology MUST Mirpur AJK-Pakistan \\ 4. Department of Food Science and Technology, Faculty of Agriculture, University of Poonch Rawalakot, \\ 12350, AJK-Pakistan \\ *Corresponding author's email: nadrakhan.upr@gmail.com \\ Citation
}

Nadra Khan, Muhammad Jamil Ahmed, Syed Zulfiqar Ali Shah, Tariq Shehzad, Maqsood Ahmed, Saiqa Bashir and Abdul Hamid. Morphological and agronomic characterization of (Capsicum annиum L.) germplasm in Pakistan. Pure and Applied Biology. Vol. 9, Issue 2, pp1603-1612.

http://dx.doi.org/10.19045/bspab.2020.90168

\begin{tabular}{llll}
\hline \hline Received: 13/12/2019 & Revised: 25/02/2020 & Accepted: 10/03/2020 & Online First: 19/03/2020 \\
\hline \hline
\end{tabular}

\section{Abstract}

The aim of the study was to estimate the magnitude of genetic variation through the characterization of germplasm using agronomical and morphological traits. In the current investigation 38 genotypes of chilli (Capsicum annuиm) were evaluated at an agronomical and morphological level for (10 quantitative and 14 qualitative traits). A set of parameters covering different growth stages selected from the Capsicum descriptors developed by Biodiversity International Former. Qualitative traits were studied on a visual basis. Quantitative characters such as plant height ranged from $40 \mathrm{~cm}$ (36588) to $63 \mathrm{~cm}$ (36616). Fruit length and width range from $2.21 \mathrm{~cm} \mathrm{(36591)} \mathrm{to} 13.2 \mathrm{~cm}(36636)$ and $0.60 \mathrm{~cm}$ (36569) to $2.90 \mathrm{~cm}$ (36560 and 36441). Fruit weight varied from $0.85 \mathrm{~g}$ (36591) to $8.30 \mathrm{~g}$ (36651). Results obtained for yield/plant ranged from $175.49 \mathrm{~g}$ (36652) to $780.3 \mathrm{~g}$ (36616). Results demonstrated the existence of diversity between the studied genotypes and consequently, providing the opportunity of attaining genetic advances in hybridization program for particular traits under consideration.

Keywords: Agronomic traits; Chilli germplasm; Genetic diversity; Morphological traits

\section{Introduction}

Chilli peppers are used as vegetable and spices globally. It has been using since the beginning of civilizations. Bosland [1] reported that this ranked the chilli amongst the oldest cultivated crops of the Americas. According to Heiser [2] genus Capsicum is one of the first crop plants being grown in the New World with maize, beans and cucurbits. It is belonging to nightshade family Solanaceae, tribe Solanaceae, subtribe Capsicinae [3]. Most Capsicum species are $2 n=2 x=24$. Some of the non- domesticated species are $2 \mathrm{n}=2 \mathrm{x}=32$ [4]. The names of variety depending on type and location and the common names of pepper are chilli, red pepper, green bell or only pepper [5]. It is originated from South and Central America [6].

Mexico, as the centre of domestication and genetic diversity of Capsicum. It is considered as the first condiment to have been utilized by human beings and there is archaeological evidence of pepper and other fossil foods from as early as 6000 years ago [7]. The pungent varieties are 
generally named chilli pepper or simply "chilli". It plays very important role in commercial sector. Specially, it is used in cosmetics, pharmaceutical industries, and for oleoresin preparation. Chilli extensively grown for making powder is also harvested green. There are many nutritional, medicinal and economic benefits of its production. It is used for salad and as condiment also. It is used in foods for pungency and red colour.

It is a small perennial shrub characterized by greenish-white corolla or white, more than one pedicel at a node having different fruit shapes and sizes [8]. Pepper grows relatively rapid with a maturity time of 3-4 months. It grown as an annual in the temperate region [9]. It grows on different types of soil but is most appropriate to welldrained loamy soils, rich in lime, with a $\mathrm{pH}$ of 5.5-6.8 and more water holding capacity. The optimum day temperatures for chilli pepper growth range from 20 to $30{ }^{\circ} \mathrm{C}$ [10]. It is often a cross-pollinated crop up to $63 \%$. Pakistan is among the major chillies exporter and producer viz China, Mexico, Morocco and Turkey. In a global scenario, India is contributing (11 lac ton) $25 \%$. The global chilli production is approximately 7 million ton cultivated on 1.5 million hectares. Among top chilli producing and export countries, India exports $25 \%$, China $24 \%$, Spain $17 \%$, Mexico 8\%, Pakistan $7.2 \%$, Morocco $7 \%$ and Turkey $5 \%$ are respectively. Badin, Mirpur khas and Umerkot, districts of Sindh represent the national clusters of red chillies production. A town of Kunri in Umerkot, contributes about $86 \%$ share in chilli production and is known as one of the leading production centers in Asia for red chillies [11]. Land of Pakistan blessed with varied types of climate and soil that grow various exogenous and indigenous medicinal plants, condiments, bearing plants and herbs. Regardless of the availability of the diverse agro-climatic conditions of the country, to produce the extensive range of plant species and as they were contributing in the national economy, by producing significant export earnings or import exchange [12].

Phenotypic characters such as plant height, fruit shape, fruit weight and flower colour have been used to differentiate genotypes of peppers and categorize them into groups [13]. Smith and Smith [14] reported that the use of phenotypic traits in categorizing and describing of germplasm is an important step in every characterization program. Morphological and conventional markers called descriptor used for identification of variety and genetic diversity in a plant. The aim of this study was to characterize germplasm using agronomical and morphological traits. This evaluation contributes to estimate the variability of the genotypes and also to determine promising materials appropriate for hybridization programs.

\section{Materials and methods}

\section{Material collection and site selection}

This study was conducted at Bio-resources and Conservation Institute (BCI), National Agricultural Research Centre (NARC), Islamabad. The plant material comprised of about 38 genotypes of pepper including a check variety (P6). The germplasm was obtained from Bio-resources and Conservation Institute (BCI), National Agricultural Research Centre (NARC), Islamabad.

Nursery of Capsicum was raised in greenhouse at NARC. The nursery was watered daily in the morning and evening till the seed was germinated. Care was taken to avoid too much watering to prevent lodging of seedlings. Field plants were transplanted after 35 days in a field in an augmented design with a plant to plant and row to row distance $45 \mathrm{~cm}$ and $75 \mathrm{~cm}$ respectively. The land was prepared by ploughing two times to level the field. Cultural practices and plant protection measurements were carried out when required raising a healthy crop. After transplanting, insecticide Lambda was sprayed on the plants to guard against the attack of tobacco caterpillar. Furadon was also used to control the cut warm. 
A set of parameters covering different growth stages selected from the Capsicum descriptors developed by Biodiversity International former [15] for recording the data on agronomic traits. Information on the phenotype given by descriptors on morphological parameters is essential in giving accurate identification of species [3]. Ten plants of each genotype were selected randomly for data recording. Fourteen morphological (qualitative) traits were studied on a visual basis as shown in (Table $1)$.

Data on the agronomical (quantitative) traits regarding Plant height $(\mathrm{cm})$ of each pepper, plant was recorded. The $1^{\text {st }}$ fruit has begun to ripe. Mature leaf width $(\mathrm{cm})$ and Leaf length $(\mathrm{cm})$, leaf length was measure from base to the endpoint of the leaf whereas width was recorded at the widest point of the leaf, after maturity of the plant. Fruit width $(\mathrm{cm})$ was measured at the widest point. Fruit length $(\mathrm{cm})$ was recorded at the largest point. Fruit weight (g) was measured by weighing the fruits after picking. Fruit wall thickness (mm) was recorded at the second harvest at the point of maximum width. A number of locules was counted by cutting fruit at the broadest point. Fruit yield per plant (g) total fruit weight of each plant of each genotype was recorded.

Table 1. Descriptor developed by Biodiversity International (former IPGRI, Rome) for recording the data on qualitative traits

\begin{tabular}{|c|c|c|}
\hline Parameters & Codes & $2 \times \sqrt{20}$ \\
\hline Life cycle & $1,2,3$ & Annual, Biennial, Perennial \\
\hline $\begin{array}{l}\text { Stem color: Recorded before transplanting on } \\
\text { young plants }\end{array}$ & $1,2,3,4$ & $\begin{array}{l}\text { Green ,Green with purple stripes, } \\
\text { Purple, Other }\end{array}$ \\
\hline $\begin{array}{l}\text { Stem pubescence: Observed on mature plants, } \\
\text { excluding of the first } 2 \text { nodes below the shoot } \\
\text { (SP) }\end{array}$ & $3,5,7$ & Sparse,Intermediate, Dense \\
\hline Leaf shape (LS) & $1,2,3$ & Deltoid, Ovate, Lanceolate \\
\hline Lamina margin (LM) & $1,2,3$ & Entire Undulate, Ciliate \\
\hline $\begin{array}{c}\text { Leaf pubescence: Recorded on young mature } \\
\text { leaves (LP) }\end{array}$ & $3,5,7$ & Sparse,Intermediate, Dense \\
\hline $\begin{array}{c}\text { Flower position: Observed on completely open } \\
\text { fresh flowers (FP) }\end{array}$ & $3,5,7$ & Pendant, Intermediate, Erect \\
\hline $\begin{array}{l}\text { Fruit colour at intermediate stage Observed on } \\
\text { fruits just before ripening stage }\end{array}$ & $1,2,3,4$ & White, Yellow, Green, Orange \\
\hline $\begin{array}{l}\text { Fruit colour at } \\
\text { mature stage }\end{array}$ & $\begin{array}{c}1,2,3,4,5,6 \\
7,8\end{array}$ & $\begin{array}{c}\text { White ,Lemon-yellow, Pale yellow, } \\
\text { orange-yellow, Orange, Light red, } \\
\text { Red, Dark red }\end{array}$ \\
\hline Fruit Shape (FS) & $1,2,3,4,5,6$ & $\begin{array}{l}\text { Elongate Almost round, Triangle, } \\
\text { Campanulate, Blocky, Other }\end{array}$ \\
\hline Fruit Shape at Pedicel Attachment & $1,2,3,4,5,6$ & $\begin{array}{l}\text { Acute, Cordate, Obtuse, Lobate, } \\
\text { Truncate }\end{array}$ \\
\hline Neck at base of fruit & $\mathbf{0 , 1}$ & Absent ,Present \\
\hline Seed colour $(\mathrm{SC})$ & $1,2,3,4$ & $\begin{array}{c}\text { Straw (deep yellow) Brown, Black, } \\
\text { Other }\end{array}$ \\
\hline Fruit Surface (FC) & $1,2,3$ & Smooth, Semi wrinkled Wrinkled \\
\hline
\end{tabular}

\section{Statistical analysis}

Means were calculated through formula $\left(\sum x / n\right)$ for all quantitative traits. Standard error, mean, standard deviation, variance, the range was calculated through descriptive stat using Microsoft excel.

\section{Results and discussion}

Morphological characterization is a procedure, which requires a descriptive list, suggested by [16] to provide more information about gene pool preserved in gene banks and working collections.

Morphological characterization is the only way of differentiation of genotypes on the 
basis of physical appearance. It is also very useful for bringing agronomically important traits, especially quantitative characters for improvement of the crop [17]. However it is also vital in genotypic identification, its application is greatly affected by prevailing environmental conditions and making the results locationspecific [17, 18]. Smith and Smith [14] reported that the use of phenotypic traits in classifying and describing germplasm is rudimentary in any characterization program. All genotypes were characterized for different agro-morphological characters as shown in (Table 2). All parameters were measured in the laboratory and field at the usual harvest time.

Variability based of morphological traits Data concerning morphology about 14 qualitative traits were estimated by the following data descriptor. Qualitative characteristics were determined on visual basis. According to the data descriptor all the qualitative traits are assigned with the code, data were recorded in the form of specific codes. All 38 genotypes showed $(100 \%)$ result regarding the annual life cycle, might be due to inherent characteristics. Data regarding to the stem colour, green colour $(84.21 \%)$ was depicted in 32 genotypes. Intermediate stem pubescence was dominant in 29 genotypes with $76.31 \%$ in frequency. Results concerning leaf shape, ovate leaf shape $(44.73 \%)$ were recorded in 17 genotypes. Data regarding lamina margin we found 32 genotypes showed undulate lamina margin with $84.21 \%$. Results related leaf pubescence, as shown in (Table 2), 18 genotypes $(47.36 \%)$ had sparse pubescence. Manju and Sreelathakumary [19] found sparse leaf pubescence in Capsicum chinense germplasm. Datta and Das [20] reported that maximum of the genotypes exhibited sparse leaf pubescence in Capsicum annum. Data regarding flower position, maximum 23 genotypes showed $(63.52 \%)$ intermediate position [21] reported that flower position in most of the genotypes, especially the wild cultivars had erect positions. Data regarding fruit colour at intermediate stage, maximum 26 genotypes depicted orange colour at intermediate stage with $68.42 \%$ frequency. Highest 22 genotypes showed dark red colour $(57.89 \%)$ at mature stage of fruit. Elongate fruit shape was prominent in 29 genotypes with $76.39 \%$. Lobate fruit shape at pedicle attachment was dominant in 24 genotypes with $63.15 \%$. Neck at the base of fruit was present in 25 genotypes with $65.78 \%$ frequency. Seed colour 36 genotypes $(98.73 \%)$ showed yellow colour of seed and 2 genotypes showed black seed colour might be due to immature seed extraction. Fifty percent of genotypes had smooth fruit surface, were found in 19 genotypes.

Table 2. List of qualitative characters recorded on the base of visual observation

\begin{tabular}{|c|c|c|c|}
\hline S. No. & Parameters & Frequency & \% age \\
\hline $\mathbf{1}$ & Lnnual & 38 & 100 \\
\hline & Biennial & & \\
\hline & Perenial Stem color (SC) & \\
\hline $\mathbf{2}$ & 1.Green & 32 & 84.21 \\
\hline & 3.Purple & 2 & 5.2 \\
\hline & 4.Other & 4 & 0 \\
\hline & 3.Sparse & 0 & 13.15 \\
\hline & 5.Intermediate & 5 & 76.31 \\
\hline $\mathbf{3}$ & 7.Dense & 29 & 10.52 \\
\hline & 1.Deltoid & 4 & 42.10 \\
\hline $\mathbf{4}$ & 2.Ovate & 16 & 44.73 \\
\hline & \multicolumn{2}{|c|}{ Leaf Shape (LS) } \\
\hline
\end{tabular}




\begin{tabular}{|c|c|c|c|}
\hline & 3.Lanceolate & 5 & 13.15 \\
\hline \multirow[t]{4}{*}{5} & \multicolumn{3}{|c|}{ Lamina Margin (LM) } \\
\hline & 1.Entire & 5 & 13.15 \\
\hline & 2.Undulate & 32 & 84.21 \\
\hline & 3.Ciliate & 1 & 2.63 \\
\hline \multirow[t]{4}{*}{6} & \multicolumn{3}{|c|}{ Leaf Pubescence (PB) } \\
\hline & 3.Sparse & 18 & 47.36 \\
\hline & 5.Intermediate & 16 & 42.10 \\
\hline & 7.Dense & 4 & 10.52 \\
\hline \multirow[t]{4}{*}{7} & \multicolumn{3}{|c|}{ Flower position (FP) } \\
\hline & 3.Pendant & 7 & 18.42 \\
\hline & 5.Intermediate & 23 & 60.52 \\
\hline & 7.Erect & 8 & 21.05 \\
\hline \multirow[t]{8}{*}{8} & \multicolumn{3}{|c|}{ Fruit Colour at Intermediate Stage } \\
\hline & 1.White & 0 & 0 \\
\hline & 2.Yellow & 1 & 2.63 \\
\hline & 3.Green & 10 & 26.31 \\
\hline & 4.Orange & 26 & 68.42 \\
\hline & 5.Purple & 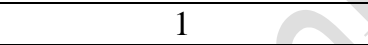 & 2.63 \\
\hline & 6.Deep purple & ( & 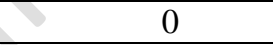 \\
\hline & 7.Other & 0 & 0 \\
\hline \multirow[t]{13}{*}{9} & \multicolumn{3}{|c|}{ Fruit Colour at Mature Stage } \\
\hline & 1.White & 0 & 0 \\
\hline & 2.Lemon-yellow & 0 & 0 \\
\hline & 3.Pale orange-yellow & 0 & 0 \\
\hline & 4.Orange yellow & 1 & 0 \\
\hline & 5.Pale orange & 0 & 0 \\
\hline & 6.Orange & $\begin{array}{r}4 \\
\end{array}$ & 10.52 \\
\hline & 7.Light red & 10 & 26.31 \\
\hline & 9.Dark red & 22 & 57.89 \\
\hline & 10 Purple & 0 & 0 \\
\hline & 11.Brown & 0 & 0 \\
\hline & 12.Black & 0 & 0 \\
\hline & 13.Other & 0 & 0 \\
\hline \multirow[t]{6}{*}{10} & \multicolumn{3}{|c|}{ Fruit Shape (FS) } \\
\hline & 1.Elongate & 29 & 76.31 \\
\hline & 2.Almost round & 7 & 18.42 \\
\hline & 3.Triangle & 0 & 0 \\
\hline & 4.Campanulate & 0 & 0 \\
\hline & 5.Blocky & 2 & 5.26 \\
\hline \multirow[t]{2}{*}{11} & \multicolumn{3}{|c|}{ Fruit Shape at Pedicel Attachment } \\
\hline & 1.Acute & 7 & 18.42 \\
\hline$\overline{0}$ & 2.Cordate & 2 & 5.2 \\
\hline & 3.Obtuse & 0 & 0 \\
\hline & 4.Lobate & 24 & 63.15 \\
\hline 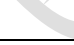 & 5.Truncate & 5 & 13.15 \\
\hline \multirow[t]{3}{*}{12} & \multicolumn{3}{|c|}{ Neck at Base of Fruit } \\
\hline & 0. Absent & 13 & 34.21 \\
\hline & 1.Present & 25 & 65.78 \\
\hline \multirow[t]{5}{*}{13} & \multicolumn{3}{|c|}{ Seed Colour (SC) } \\
\hline & 1.Straw (deep yelow) & 36 & 94.73 \\
\hline & 2.Brown & 0 & 0 \\
\hline & 3.Black & 2 & 5.20 \\
\hline & 4.Other & 0 & 0 \\
\hline 14 & Fruit & urface (FC) & \\
\hline & 1.Smooth & 19 & 50 \\
\hline & 2.Semiwrinkled & 16 & 42.10 \\
\hline & 3.Wrinkled & 3 & 7.89 \\
\hline
\end{tabular}




\section{Variability based on agronomic traits}

The explanation of morphological character, variation is very significant in the commencement of programs intended with the selection of genotypes having quantitative characters like yield, fruit weight, length and width of fruit. Genetic variability evaluation includes mean and range which supports in the selection of genotypes as these designate characteristic of genotypes. Mean and range for 10 quantitative traits for all set of genotypes are given in (Table 3). The magnitude of variability existing in the genotypes was measured in terms of general mean, standard deviation, range and variance. It is important character for the selection purpose. (Fig. 1) displayed variation among the genotypes regarding to fruit size shape and colour.

In present investigation, data collected regarding the plant height showed considerable differences among set of genotypes. Range of plant height varied from $40 \mathrm{~cm}$ to $63 \mathrm{~cm}$ with the mean value $52.51 \pm 2.58$ as shown in (Table 3 ). Highest $(63 \mathrm{~cm})$ plant height was seen in 36645 and 36616 . Lowest ( 40 and $41 \mathrm{~cm}$ ) plant height was observed in 36588 and 36591 genotypes. A variety P6 showed $60 \mathrm{~cm}$ of plant height. Similar results were observed in investigation of [22]. The variation in growth of pepper plant is controlled by environmental factors mainly moisture, humidity, temperature, light, soil fertility and environment etc.

Leaves are the main organ for photosynthesis and play a vital role in the growth and survival of plant. Data recorded for leaf width varied from $(1.10 \mathrm{~cm}$ to 4.50 $\mathrm{cm})$ with mean value of $2.76 \pm 0.15$ shown in (Table 4). Maximum (4.5, 4.3, 4.3, 4.2 and $4.1 \mathrm{~cm})$ leaf width in overall set of genotypes was found in genotype 36636 whereas minimum $(1.1 \mathrm{~cm})$ was noted in 36565 genotypes. Data concerning leaf length, range of leaf length varied from (2.1 $\mathrm{cm}$ to $5.77 \mathrm{~cm}$ ) with mean values $3.82 \pm 0.18$. Maximum $(5.7$ and $5.6 \mathrm{~cm}$ ) leaf length was seen in 36617 and 36597 genotypes whereas P6 showed $(3.1 \mathrm{~cm})$ of leaf length Minimum $(2.1 \mathrm{~cm})$ leaf length was recorded in 36651. Many previous investigations have shown that variations in leaf character are the outcome of adapting to growth habitat [23]. Our results are in accordance with [24].

Data regarding to number of locules recorded from tested cultivars range from 1.50 to 2.20 with mean value of $1.97 \pm 0.02$. Maximum (2.20) number of locules was observed in 36624 followed by (2.21) was seen in 36632 genotype while minimum (1.50) was seen 36637 genotype. A variety P6 showed (2) number of locules. Lippman and Tanksley [25] reported that some varieties produced fruit with more number of locules, resulting in wider and larger fruit.

The fruit width and length are leading traits, help in differentiating the varieties as small, medium, and large size. Results obtained for fruit width range from $0.60 \mathrm{~cm}$ to 2.90 $\mathrm{cm}$ with mean value of $1.63 \pm 0.11$. Maximum (2.90) fruit width was found in 36114 and 36560 genotypes. Minimum (0.60) fruit width was found in 36569. The data presented considerable variation regarding fruit length and width among the Capsicum genotypes as shown in (Fig. 1).

The Capsicum genotypes displayed significant variability concerning fruit length, range of fruit length varied from $2.21 \mathrm{~cm}$ to $13.2 \mathrm{~cm}$ with the mean value $7.06 \pm 0.55$. Maximum $(13.2 \mathrm{~cm})$ fruit length was observed in genotype 36636. Minimum $(2.1 \mathrm{~cm})$ fruit length was observed in 36591. Enough variation was seen in length and width of fruit is due to long and thin fruits wide fruits of chillies as shown in (Fig. 1). These findings are in accordance with [26, 27] also found that pepper cultivars and varieties varied significantly in fruit length, width and weight.

Fruit wall thickness is also most influential element in yield [28]. Firm fruits are appropriate for picking, transportation, storage and marketing. It was measured in millimetre. Fruit wall thicknesss varied from $(0.51$ to $2.60 \mathrm{~mm})$ with a mean value 
of $1.35 \pm 0.10$. Highest $(2.6 \mathrm{~mm})$ pericarp thickness was found in genotype 33828. Minimum (0.51) was observed in 36635 genotypes. Check variety P6 showed (1.5 $\mathrm{mm}$ ) of fruit wall thickness.

Fruit weight is powerful characteristic for the selection process. The results of these studies demonstrated a single weight of fresh fruit/plant varied among the Capsicum genotypes from $(0.85 \mathrm{~g}$ to $8.30 \mathrm{~g})$ with the mean value $3.56 \pm 0.29$. Maximum $(8.3 \mathrm{~g})$ was observed in genotype 36651 , while minimum $(0.85 \mathrm{~g})$ fruit weight was found in genotype 36591. Wide variation related to fruit weight was recorded among genotypes due to small, medium, large/wide genotypes. Fruit weight is quantitatively hereditary trait, controlled by many genetic loci, some with a minor effect and other with large effect [29]. Fruit weight has a maximum contribution towards increase in yield/ plant.

Number of fruit also important trait, contribute to the final yield. Data regarding number of fruit varied from (37.1 to 298.0) with mean value of $148.20 \pm 9.55$. Highest (298.0) number of fruit was observed in genotype 36613 while lowest (37.1) was found in genotype 36652. About (154.3) numbers of fruit were observed in p6 variety. Our results are in accordance with [30].

Yield is a multipart trait and determined by numerous factors. The variation in quality characters and yield is determined by environmental factors and genetic of plant [31]. But yield constituents are somewhat simple and little affected by the environmental factors. Data concerning yield varied from $175.49 \mathrm{~g}$ to $780.3 \mathrm{~g}$ with the mean value of $521.02 \pm 28.01$. Maximum $(780.3 \mathrm{~g})$ yield/plant was observed in genotype 36616 while minimum (175.94 g) was seen in genotype 36652. Whereas (509.80) g yield/plant was depicted in P6. This variation was recorded for fruit length $(\mathrm{cm})$, fruit weight $(\mathrm{g})$, plant height $(\mathrm{cm})$, and in fruit yield per plant of different Capsicum genotypes, due to their heredity characteristics and response of genotypes to the fluctuating environmental factors, fertilization, disease and pest, control management, processing and harvesting methods during growing season. Genotypes displayed great variation for all the evaluated traits, confirming the affirmation of [32].

Table 3. Descriptive statistics for the (agronomic) quantitative traits

\begin{tabular}{|c|c|c|c|c|c|c|}
\hline \multirow{2}{*}{ Traits } & \multirow{2}{*}{ Mean } & \multirow{2}{*}{ SD } & \multirow{2}{*}{ Variance } & \multicolumn{2}{|c|}{ Range } & \multirow{2}{*}{$\begin{array}{c}\text { Check variety } \\
\text { P6 }\end{array}$} \\
\hline & & & & Maximum & Minimum & \\
\hline Plant height & $52.51 \pm 2.58$ & 8.00 & 64.06 & 63 & 40 & 60.1 \\
\hline $\begin{array}{c}\begin{array}{c}\text { Leaf width } \\
(\mathrm{cm})\end{array} \\
\end{array}$ & $2.76 \pm 0.15$ & 0.93 & 0.86 & 4.50 & 1.10 & 2.83 \\
\hline $\begin{array}{l}\text { Leaf length } \\
(\mathrm{cm})\end{array}$ & $3.82 \pm 0.18$ & 1.16 & 1.36 & 5.77 & 2.1 & 3.1 \\
\hline $\begin{array}{c}\text { Number of } \\
\text { locules }\end{array}$ & $1.97 \pm 0.02$ & 0.15 & 0.02 & 2.20 & 1.50 & 2 \\
\hline $\begin{array}{l}\text { Fruit width } \\
\text { (cm) }\end{array}$ & $1.63 \pm 0.11$ & 0.69 & 0.48 & 2.90 & 0.60 & 2.6 \\
\hline $\begin{array}{c}\text { Fruit length } \\
(\mathrm{cm})\end{array}$ & $7.06 \pm 0.55$ & 3.51 & 12.29 & 13.2 & 2.21 & 9.86 \\
\hline $\begin{array}{c}\text { Fruit wall } \\
\text { thickness (mm) }\end{array}$ & $1.35 \pm 0.10$ & 0.63 & 0.40 & 2.60 & 0.51 & 1.5 \\
\hline $\begin{array}{c}\text { Single Fruit } \\
\text { weight }(g)\end{array}$ & $3.56 \pm 0.29$ & 1.67 & 2.81 & 8.30 & 0.85 & 3.38 \\
\hline $\begin{array}{l}\text { Number of } \\
\text { fruit/ plant }\end{array}$ & $148.20 \pm 9.55$ & 60.38 & 2905.29 & 298.0 & 37.1 & 154.3 \\
\hline Yield/plant (g) & $\begin{array}{c}521.02 \pm 28.0 \\
1\end{array}$ & 177.14 & 28043.38 & 780.3 & 175.49 & 509.80 \\
\hline
\end{tabular}



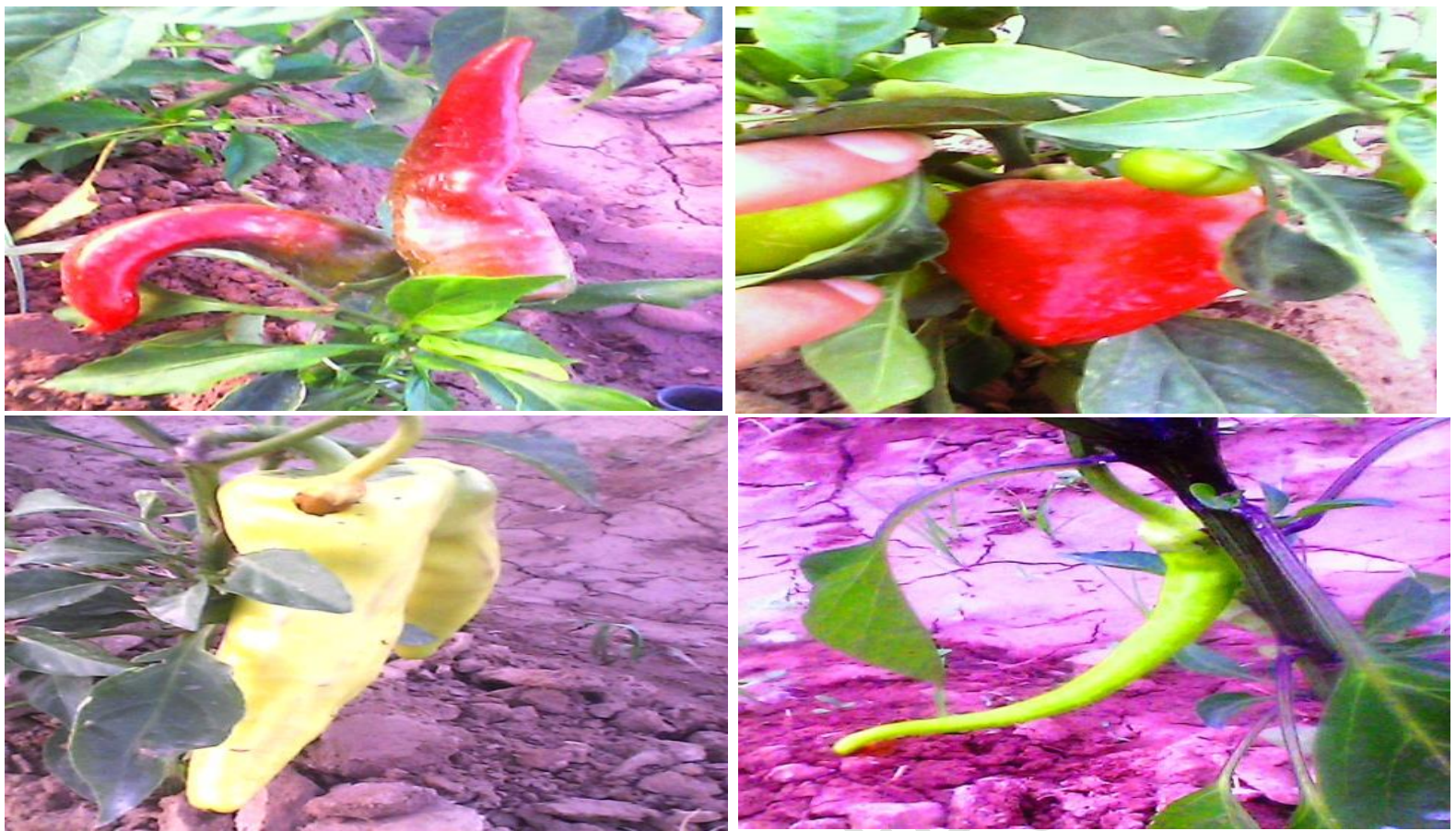

Figure 1. Diversity shown among pepper genotypes regarding: shape of fruit, fruit size and fruit colour at mature stage

Table 4. Means values of agronomic (quantitative) parameters

\begin{tabular}{|c|c|c|c|c|c|c|c|c|c|c|c|}
\hline $\begin{array}{c}\text { Genoty } \\
\text { pe ID }\end{array}$ & $\begin{array}{c}\text { PH } \\
(\mathrm{cm})\end{array}$ & $\begin{array}{c}\mathbf{L W} \\
(\mathrm{cm})\end{array}$ & $\mathbf{L L}(\mathbf{c m})$ & NOL & $\begin{array}{l}\text { FW } \\
(\mathbf{c m})\end{array}$ & $\begin{array}{l}\text { FL } \\
(\mathrm{cm})\end{array}$ & $\begin{array}{l}\text { FW } \\
(\mathrm{cm})\end{array}$ & $\begin{array}{l}\text { FWT } \\
(\mathbf{m m}) \\
\end{array}$ & $\begin{array}{c}\text { SFW } \\
(\mathrm{g})\end{array}$ & $\mathbf{N F} / \mathbf{P}$ & $\begin{array}{l}/ P \\
(g)\end{array}$ \\
\hline 36637 & 43 & 1.8 & 4.6 & 1.5 & 0.98 & 5.1 & 0.98 & 0.67 & 2.59 & 123.1 & 520 \\
\hline 36635 & 43 & 2.8 & 2.9 & 2 & 0.97 & 6.87 & 0.97 & 0.51 & 3.65 & 140.23 & 419.8 \\
\hline 36620 & 44 & 1.3 & 5 & 2 & 1.7 & 4.7 & 1.7 & 1.5 & 4.6 & 191.34 & 566.75 \\
\hline 36588 & 40 & 2.8 & 4.4 & 2 & 1.3 & 3.6 & 1.3 & 0.66 & 1.45 & 100.23 & 398.7 \\
\hline 36622 & 49.23 & 4.3 & 2.5 & 2 & 1.1 & 4.9 & 1.1 & 1 & 1.84 & 87.4 & 286.5 \\
\hline 36624 & 60.23 & 1.2 & 2.7 & 2.2 & 1.65 & 8.87 & 1.65 & 1.3 & 3.85 & 156.6 & 699.5 \\
\hline 36636 & 62 & 4.5 & 4.6 & 2 & 1.97 & 13.2 & 1.97 & 2.3 & 7.45 & 200.45 & 777.1 \\
\hline 36592 & 60.13 & 2.9 & 3.2 & 2 & 1.72 & 9.21 & 1.72 & 0.93 & 3.69 & 165.44 & 645.2 \\
\hline $\mathbf{3 6 5 9 7}$ & 60.45 & 3.3 & 5.6 & 1.7 & 1.35 & 5.8 & 1.35 & 1.2 & 3.4 & 164.8 & 579.43 \\
\hline 36591 & 41 & 1.9 & 2.3 & 2 & 2.48 & 2.1 & 2.48 & 1.9 & 0.85 & 174 & 250.3 \\
\hline 36632 & 46 & 1.5 & 2.2 & 2.2 & 0.8 & 5.6 & 0.8 & 0.9 & 3.7 & 219.8 & 660.34 \\
\hline 36617 & 61 & 4.2 & 5.6 & 2 & 0.7 & 2.8 & 0.7 & 1.1 & 2.6 & 218 & 561.922 \\
\hline 36623 & 45 & 1.4 & 2.8 & 2 & 1.5 & 4.5 & 1.5 & 0.77 & 1.56 & 194.3 & 475.8 \\
\hline 36616 & 63 & 3.9 & 5 & 2 & 1.7 & 3.1 & 1.7 & 1.1 & 2.4 & 298 & 780.3 \\
\hline 36628 & 57 & 4.3 & 5.3 & 1.7 & 1.2 & 5.8 & 1.2 & 1.2 & 2.8 & 278.9 & 715.47 \\
\hline 36612 & 59 & 2.5 & 2.1 & 2 & 1.5 & 6.3 & 1.5 & 1.6 & 3.18 & 99.3 & 423.9 \\
\hline 36114 & 60 & 2.2 & 5.4 & 2 & 2.9 & 7.43 & 2.9 & 2.5 & 4 & 142.5 & 567.34 \\
\hline 36649 & 47 & 3.7 & 4.2 & 1.8 & 1 & 6.7 & 1 & 1 & 3.87 & 145 & 230 \\
\hline 30881 & 45.12 & 3.1 & 4.2 & 2 & 0.7 & 3.7 & 0.7 & 0.66 & 1.5 & 206.6 & 360.55 \\
\hline 36570 & 61 & 2.1 & 3.3 & 2 & 1 & 7.2 & 1 & 1 & 4 & 107.4 & 629.23 \\
\hline 36569 & 46 & 2.7 & 5.1 & 2 & 0.6 & 3.8 & 0.6 & 0.7 & 1.4 & 149.2 & 420.71 \\
\hline 36627 & 47 & 2.1 & 3.1 & 2 & 2.5 & 12.0 & 2.5 & 2.4 & 7.2 & 79.82 & 509.8 \\
\hline 30879 & 58 & 2.4 & 5.1 & 2 & 1.4 & 5.4 & 1.4 & 0.98 & 2.33 & 128.9 & 500.12 \\
\hline 36565 & 59.23 & 1.1 & 2.3 & 2.1 & 2.82 & 8.57 & 2.82 & 1.3 & 3.55 & 147.67 & 635.4 \\
\hline 36560 & 60 & 2.8 & 3.1 & 1.9 & 2.9 & 9.24 & 2.9 & 0.9 & 3.65 & 154 & 698.2 \\
\hline 33828 & 55 & 4.1 & 5.3 & 2 & 1.8 & 11.8 & 1.8 & 2.6 & 6.5 & 148 & 667.8 \\
\hline 36563 & 61 & 3 & 3.2 & 2 & 1.7 & 7.3 & 1.7 & 2.2 & 3.5 & 152.3 & 572.594 \\
\hline 36644 & 58 & 3.5 & 4.2 & 2 & 1.4 & 8.1 & 1.4 & 1.4 & 4.56 & 123.4 & 612.4 \\
\hline
\end{tabular}




\begin{tabular}{|c|c|c|c|c|c|c|c|c|c|c|c|}
\hline $\mathbf{3 6 6 4 5}$ & 63 & 2.2 & 4.1 & 1.9 & 1.3 & 5.3 & 1.3 & 1.6 & 2.67 & 164.4 & 625.43 \\
\hline $\mathbf{3 6 6 5 8}$ & 57 & 3.7 & 2.4 & 2 & 1.3 & 6.9 & 1.3 & 0.67 & 2.87 & 156.7 & 531.43 \\
\hline $\mathbf{3 6 6 3 0}$ & 47 & 1.9 & 4.3 & 2 & 1.7 & 4.5 & 1.7 & 0.8 & 2.09 & 100.34 & 194.3 \\
\hline $\mathbf{3 0 8 7 7}$ & 49 & 3 & 2.9 & 2 & 2.7 & 11.2 & 2.7 & 2.3 & 5.7 & 97 & 703.4 \\
\hline $\mathbf{3 6 6 5 1}$ & 42 & 3 & 2.1 & 2 & 2.8 & 10.9 & 2.8 & 1.9 & 8.30 & 98 & 713.5 \\
\hline $\mathbf{3 6 6 5 2}$ & 42 & 3.5 & 5.2 & 2 & 1.7 & 8.54 & 1.7 & 1.5 & 4.19 & 37.1 & 175.94 \\
\hline $\mathbf{3 6 5 5 8}$ & 46 & 2.5 & 4.6 & 2 & 1.6 & 5.6 & 1.6 & 1.93 & 3.98 & 49.5 & 194.57 \\
\hline $\mathbf{3 6 5 6 4}$ & 48 & 3.2 & 2.5 & 2 & 1.23 & 7.6 & 1.23 & 1.98 & 3.27 & 137 & 476.44 \\
\hline $\mathbf{3 6 6 5 6}$ & 49 & 2 & 4.9 & 2 & 1.6 & 7.6 & 1.6 & 0.69 & 3.1 & 140.2 & 498.7 \\
\hline P6 & 60.1 & 2.8 & 3.1 & 2 & 2.6 & 9.86 & 2.6 & 1.5 & 3.38 & 154.3 & 509.80 \\
\hline
\end{tabular}

Plant height: PH, Leaf width, LW leaf length: LL, Number of Locules: NOL, Fruit width: FW, Fruit wall thickness: FWT, Single fruit weight: SFW, Number of fruit per plant: NF/P, Yield per plant: Y/P

\section{Conclusion}

Chilli is an essential cash crop, cultivated for spices and food all over the world. It is also used in medicines with lots of benefits to human health. Estimating unique genotypes in this study it was possible to find immense genetic variation at phenotypic level in Capsicum genotypes in climatic condition of Pakistan. We have selected 4 genotypes 36616, 36613, 36636 and 36560 on the basis of best performing morphological characters among whole set of genotypes characters These genotypes are potential source of genes for breeding programs for development of cultivar for food consumption.

\section{Authors' contributions}

Conceived and designed the experiments: $\mathrm{N}$ Khan \& MJ Ahmed, Performed the experiments: N Khan, Analyzed the data: N Khan, Contributed materials/ analysis/ tools: T Shehzad, M Ahmed, S Bashir \& A Hamid, Wrote the paper: N Khan.

\section{References}

1. Bosland PW (1996). Capsicums: Innovative uses of an ancient crop. In: J. Janick (Ed.), Progress in New Crops. ASHS Press; Arlington, VA, pp 479-487.

2. Heiser CB (1973). Seed to Civilization: The Story of Man's Food, San Francisco, California.

3. Dias GB, Gomes VMT, Moraes MS, Zottich UP, Rabelo GR, Carvalho AO, Moulin M, Goncalves LSA, Rodrigues R, \& Cunha M (2013). Characterization of Capsicum species using anatomical and molecular data. Gen Mol Res 4(2): 1-14.

4. Bosland PW \& Votava EJ (2000). Peppers: vegetable and spice capsicums. New York: CABI Publishing, pp 204.
5. Faustino JMFM, Barroc J \& Guine RPF (2007). Study of the drying kinetics of green bell pepper and chemical characterization. Food Biprod Process 85: 163-170.

6. Grubben GJH \& Tahir IM (2004). (Capsicum annuum L.). Prota Foundation, Wageningen, Netherlands. Backhuys Publishers, Leiden, Netherlands/ CTA, Wageningen, Netherlands, pp 154-163.

7. Hill TA, Ashrafi H, Reyes-Chin-Wo S, Yao J, Stoffel K, Truco MA, Kozik K, Michelmore RW \& Deynze, AV (2013). Characterization of (Capsicum annuum) genetic diversity and population structure based on parallel polymorphism discovery with a 30K Unigene Pepper Gene Chip. Plos One 8(2): 1-16.

8. Norman JC (1992). Tropical vegetable crops, pp 78-87.

9. Tindall HD (1983). Vegetables in Tropics. Macmillan press Lt.d, pp 347.

10. Bridgemohan $\mathrm{P}$, Mohammed $\mathrm{M} \&$ Bridgemohan RSH (2018). Capsicums fruit and vegetable phytochemicals: chemistry and human health. (2nd edn), Yahia EM (Ed.), John Wiley \& Sons Ltd., Hoboken, New Jersey, USA, 2(12) SBI.

11. Arin S (2019). Scenario of Chilli Production and Hindrances Faced by the Growers of Sindh Province of Pakistan. Mod Concep Dev Agrono 4(3).

12. Khan N, Ahmed MJ \& Shah ZA (2019). Comparative analysis of mineral content and proximate composition from chilli pepper (Capsicum annuum L.) germplasm. Pure Appl Biol 8(2): 1338-1347.

13. Fonseca RM, Lopes R, Barros SW, Lopes MTG \& Ferreira FM (2008). Morphological characterization and genetic diversity of (Capsicum chinense Jacq). Accessions along the upper Rio 
Negro-Amazonas. Crop Breed Appl Biot 8: 187-194.

14. Smith JSC \& Smith OS (1989). The description and assessment of distances between inbred lines of maize: the utility of morphological, biochemical and genetic descriptors and a scheme for the testing of distinctiveness between inbred lines. Maydica 34: 151-161.

15. IPGRI, 1995. Descriptors for Capsicum (Capsicum spp.). Roma: International Plant Genetic Resources Institute (IPGRI).

16. IPGRI, AVRDC \& CATIE (1995). Descriptors for Capsicum (Capsicum spp L.). International Plant Genetic Resources Institute, Rome, Italy; the Asian Vegetable Research and Development Center, Taipei, Taiwan, and the Centro Agronómico Tropical de Investigacion y Enseñanza, Turrialba, Costa Rica, pp 110.

17. Geleta LF \& Labuschagne MT \& Viljoen CD (2005). Genetic variability in pepper (Capsicum annuum L.) estimated by morphological data and amplified fragment length polymorphism markers. Biodivers Conserv 14: 2361-2375.

18. Gepts $P$ (1993). The use of molecular and biochemical markers in crop evolution studies. Evol Biol 27: 15-94.

19. Manju P \& Sreelathakumary R (2004). Genetic divergence in hot chilli. Capsicum and Egg Plant Newsletter 23: 69-72.

20. Datta S \& Das L (2013). Characterization and genetic variability analysis in Capsicum annuum L. germplasm. Saarc $J$ Agri 11(1): 91-103.

21. Castanon-Najera G, Latournerie-Moreno L, Mendoza-Elos M, Vargas-Lopez A \& Cardenas-Morales H (2008). Coleccion y caracterizacion de chile (Capsicum spp.) en Tabasco, Mexico. Phyton Int J Exp Bot 77: 189-202.

22. Lahbib K, Fethi B \& Gazzah ME (2012). Genetic diversity evaluation of pepper (Capsicum annuum L.) in Tunisia based on morphologic characters. Afr J Agric Res 7(23): 3413-3417.

23. Siso S Camarero JJ \& Gil-Pelegrin E (2001). Relationship between hydraulic resistance and leaf morphology in broadleaf Quercusspecies: a new interpretation of leaf lobation. Trees Stru Fun 15: 341-345.

24. Acosta-Rodriguez GF \& Lujan-Favela M (2002). Selection and characterization of plants in two populations of piquin pepper (Capsicum annuum L.) in Delicias, Chihuahua. In: Proceedings of the 16th International Pepper Conference. Tampico, Tamaulipas, Mexico: Universidad Autonoma de Tamaulipas, pp 16-17.

25. Lippman Z \& Tanksley SD (2001). Dissecting the genetic pathway to extreme fruit size in tomato using a cross between the small-fruited wild species pimpinellifolium and L.esculentum, var. Giant Heirloom. Genet 158: 413-422.

26. Jarrat RL (2008). Variation for fruit morphological characteristics in a (capsicum chinense jacq.) germplasm collection. Hort Sci 43: 1694-1697.

27. Khan MAI, Hoque MA, Farooque AM, Habiba U \& Rahim AR (2012). Physiomorphological features of chilli accessions under moisture stress conditions. Bangla $J$ of Agri Res 37(2): 263-269.

28. Cankaya S Balkaya A \& Karaagac O (2010). Canonical correlation analysis for the determination of relationships between plant characters and yield components in red pepper (Capsicum annuиm L. var. conoides (Mill.) Irish) genotypes. Span J Agric Res 1(8): 67-73.

29. Paran IE \& Knaap VD (2007). Genetic and molecular regulation of fruit and plant domestication traits in tomato and pepper. $J$ Exp Bot 58: 3841-3852.

30. Yatagiri N Telugu RK, Shafiqurrahaman M \& Sanap PB (2017). Evaluation of chilli Genotypes for yield attributing and incidence of leaf curl and white fly traits in coastal Maharashtra, Ind Int $J$ Curr Microbiol App Sci 6(9): 3140-3148.

31. Zecevic B, Dordevic R, Balkaya A, Damnjanovic J, Dordevic M \& Vujosevic A (2011). Influence of parental germplasm for fruit characters in F1, F2 and F3 generations of pepper (Capsicum annuит L.). Genet 43: 209-216.

32. Pickersgill B (1997). Genetic resources and breeding of Capsicum spp. Euphytica 96(1): 129-133. 